\title{
HABITANTES TEMPORÁRIOS: O PRESSUPOSTO EPISTEMOLÓGICO DO (NÃO) SABER DOCENTE E A INVENTIVIDADE
}

\author{
HABITANTES TEMPORALES:EL PRESUPUESTO EPISTEMOLÓGICO (NO) \\ SABER DOCENTE Y LA INVENTIVIDADE
}

\author{
TEMPORARY INHABITANTS:THE EPISTEMOLOGICAL ASSUMPTION \\ TEACHING (NON) KNOWING AND INVENTIVENESS
}

\author{
Carolline SEPTIMIO ${ }^{1}$ \\ Geovana Mendonça Lunardi MENDES ${ }^{2}$ \\ Gilcilene Dias da COSTA ${ }^{3}$
}

\begin{abstract}
RESUMO: A partir da pesquisa de doutorado acerca do discurso recorrente de que falta aos professores que trabalham com Estudantes com deficiência o conhecimento necessário para o exercício da docência, este artigo busca problematizar o pressuposto epistemológico do saber docente como critério de verdade, apontando caminhos sobre o (não) saber docente frente aos desafios da escola inclusiva. Para tanto, apresentamos o artigo em dois eixos: no primeiro, discutimos a ideia de ignorância e (não) saber; no segundo, problematizamos a experiência do fora enquanto lugar de errância e inventividade. Trata-se de uma reflexão teórica fundamentada em Platão (1972), Rancière (2012; 2015), Blanchot (2005), Kohan (2015), Masschelein e Simons (2014; 2015; 2017), Larrosa (1998; 2011; 2015; 2016), entre outros. Em nossas palavras finais, escrevemos no sentido de que o (não) saber permite o erro, a descoberta do novo e a possibilidade da inventividade no espaço escolar.
\end{abstract}

PALAVRAS-CHAVE: (Não) saber. Ignorância. Formação de professores. Experiência do fora. Inventividade.

RESUMEN: A partir de la investigación de doctorado sobre el discurso recurrente que falta a los professores que trabajan con estudiantes con discapacidad el conocimiento necesario para el ejercicio de la docencia, este artículo busca problematizar el presupuesto epistemológico del saber docente como critério de la verdade, senãlando camiños sobre el (no) saber docente frente a los desafios de la escuela inclusiva. Para eso, presentamos el artículo en dos ejes: en el primer, discutimos la idea de ignorancia y (no) saber; en el segundo, problematizamos la experiencia del fuera como lugar de equivocación e inventividad. Se trata de una reflexión teórica fundamentada en Platão (1972), Rancière (2012;2015), Blanchot (2005), Kohan (2015), Masschelein y Simons (2014; 2015; 2017), Larrosa (1998; 2011; 2015; 2016), entre otros. En nuestras palabras

\footnotetext{
${ }^{1}$ Universidade do Estado de Santa Catarina (UDESC), Florianópolis - SC - Brasil. Estudante do Doutorado em educação. ORCID: <http://orcid.org/0000-0003-2669-3119>. E-mail: carolpedagoga@ yahoo.com.br ${ }^{2}$ Universidade do Estado de Santa Catarina (UDESC), Florianópolis - SC - Brasil. Professora Adjunta da UDESC. ORCID: <http://orcid.org/0000-0002-8848-7436>. E-mail: geolunardi@gmail.com ${ }^{3}$ Universidade Federal do Pará (UFPA), Belém - PA - Brasil. Professora Adjunta da UFPA. ORCID: <http://orcid.org/0000-0002-7156-5610>.E-mail: costagilcilene@gmail.com
}

RIAEE - Revista Ibero-Americana de Estudos em Educação, Araraquara, v. esp, n. 3, p. 2054-2070, dez., 2018. E-ISSN: 1982-5587. 
finales, escribimos en el sentido de que el (no) saber permite la equivocación, el descubrimiento del nuevo y la posibilidad de inventividad en el espacio escolar.

PALABRAS CLAVE: (No) saber. Ignorancia. Formación de profesores. Experiencia del fuera. Inventividad.

ABSTRACT: From the doctoral research on the recurrent discourse that is lacking to the teachers who work with students with disabilities the knowledge necessary for the exercise of teaching, this article seeks to problematize the epistemological assumption of teacher knowledge as a criterion of truth, indicating ways of teaching (non) knowing the challenges of inclusive school. Therefore, we present the article in two axes: in the first, we discuss the idea of ignorance and (not) knowing; in the second, we problematize the experience of the outside as a place of wandering and inventiveness. It is a theoretical reflection based on Platão (1972), Rancière (2012; 2015), Blanchot (2005), Kohan (2015), Masschelein and Simons (2014; 2015; 2017), Larrosa (1998; 2011; 2015; 2016), among others. In our final words, we write in the sense that (non) knowing allows error, the discovery of the new and the possibility of inventiveness in the school space.

KEYWORDS: (Non) knowing. Ignorance. Teacher training. Forums experience. Inventiveness.

\section{Introdução}

Tem sido recorrente o discurso de que falta aos professores que trabalham com Estudantes com deficiência conhecimento para o exercício da docência, de que necessitam saber mais a fim de poder lidar com os desafios da escola inclusiva. Dessa, tem sido demandada uma série de competências que antes não lhe diziam respeito, combinada ao discurso de que nada funciona quando se trata do escolar.

A inclusão de Estudantes com deficiência no contexto escolar trouxe novos questionamentos e o desejo de muitos professores em encontrar soluções aos desafios levantados. Ao mesmo tempo, a necessidade sempre presente de formações para o trabalho docente fez-se ainda mais salutar e o discurso da falta de conhecimentos para a educação de Pessoas com deficiência ainda mais constante. Portanto, debruçamo-nos sobre a temática da epistemologia do (não) saber de professores que trabalham com Estudantes com deficiência, instigadas pela seguinte questão: o que necessita (não) saber o professor para ensinar Estudantes com deficiência?

A escola sofre por se tentar fazer liberta. Nas palavras de Larrosa (2015, p. 12) "se a educação não quer estar a serviço do que existe, tem que se organizar em torno de uma categoria livre [...] tem a ver com o não-saber, com o não-poder, com o não-querer". 
Portanto, escola tem a ver com o criar, com a força do desejo do encontro entre os que não sabem, porém se veem com algum resto de amor próprio para lutar em torno de um saber liberto. A educação dessa forma se constitui como a própria experiência, como um acontecimento, um encontro que nos ocorre. Ainda pela voz de Larrosa "A experiência é o que nos passa, o que nos acontece, o que nos toca. Não o que se passa [...] Nunca se passaram tantas coisas, mas a experiência é cada vez mais rara" (LARROSA, 2015, p. 17$18)$.

Demandas cada vez maiores, formação para professores, mais demandas, maior necessidade de saberes. $\mathrm{O}$ conhecimento que cansa por não ser produzido, por ser apenas conhecimento informado, treinamento que leva à fadiga e destrói a independência, que impõe a necessidade de saber para ensinar. Mas nada que nos atravesse.

Nesse artigo, investigamos o discurso frequente de que falta aos professores que trabalham com Estudantes com deficiência o conhecimento necessário para o exercício da docência, buscando problematizar o pressuposto epistemológico do saber docente como critério de verdade e apontar caminhos acerca da importância do (não) saber docente frente aos desafios da escola inclusiva. Nossa reflexão dividiu-se em dois eixos: no primeiro, discutimos a ideia de ignorância e do (não) saber, a partir de autores como Platão (1972) e Rancière (2012; 2015); no segundo, problematizamos a experiência do fora enquanto lugar da errância e sua relação com a inventividade, com base nas leituras em Blanchot (2015), Kohan (2015), Masschelein e Simons (2014; 2015; 2017) e Larrosa (1998; 2011; 2015; 2016). Nas considerações finais expusemos prováveis desafios à escola inclusiva e apontamos algumas reflexões trazidas pela experiência do fora e a relação entre o (não) saber e inventividade no espaço escolar.

Em meio ao debate teórico, desejamos que o (não) saber revele a incerteza necessária para respirar, para suspender o tempo institucional e criar tempos livres à invenção, para fazer-se invento ao invés de imitação, para desconfiar, abrir mão das certezas doutrinárias, das amarras do conhecimento que nos impedem de ver as lacunas e a fertilidade delas.

\section{Entre saberes e não saberes e os desafios da escola inclusiva}

Saber e não saber. Parece oposto, paradoxo, contraditório, uma divisão binária. Entretanto, olhando bem perto, saberes e não saberes se pertencem, não se excluem, mas se

RIAEE - Revista Ibero-Americana de Estudos em Educação, Araraquara, v. esp, n. 3, p. 2054-2070, dez., 2018. E-ISSN: 1982-5587. 
complementam. Parte do que sabemos também comporta nosso não saber, porque todo conhecimento carrega em si a característica central da incompletude. A dúvida, que parece nossa inimiga, se faz amiga, parceira e irmã, quando finalmente compreendemos ser ela grande mobilizadora do (não) saber.

O discurso que temos presenciado é o da falta. Falta formação inicial, continuada e em serviço, falta domínio dos conteúdos para a melhoria do ensino... falta! Reconhecemos que a formação deve ser uma constante e é essencial para a busca de novos saberes, porém o que trazemos aqui é a discussão da ausência do saber tão reclamado por professores que se veem despreparados para o trabalho.

Saber e verdade. Professores que saibam ensinar nos remete à ideia do mestre que tenha a capacidade de fazer com que seu aluno aprenda, que consiga o mesmo resultado de sucesso em cada turma que por ele passar, na certeza de que aprenderam o que deveriam saber de acordo com a explicação do mestre, de que entenderam aquilo que se julga necessário entender e, caso fosse posto à prova, sabatinado, corresponderia às expectativas demonstrando que aprendeu. Isso nos parece semelhante ao critério de verdade científica sobre a qual Kohan (2015) nos explica que precisa ser reproduzida e obtido o mesmo resultado como garantia de verdade.

O discurso epistemológico educacional predominante assevera a ideia de que ao professor cabe a responsabilidade de saber mais a fim de auxiliar seu aluno, o que sabe menos e procura aprender a partir da explicação de seu mestre. Nesse sentido, o 'mestre explicador' tem por missão o domínio dos conhecimentos para ser o melhor professor, aquele que repassa ao aluno de modo mais rápido, simples e direto os saberes de que o estudante necessita. Tal mestre está bem-intencionado, é comprometido e responsável com seus afazeres. Alerta-nos Rancière (2015, p.24-25) que "O embrutecedor não é o velho mestre obtuso que entope a cabeça de seus alunos de conhecimentos indigestos [...] Ao contrário, é exatamente por ser culto, esclarecido e de boa-fé que ele é mais eficaz".

Mas onde reside o perigo de tal professor? Seriam, portanto, a displicência e o descaso as saídas propostas nesse caminho de pesquisa? Certamente não. Nossa ideia repousa naquilo que Sócrates instigou, no reconhecimento de que pouco ou nada sabemos. O filósofo sai à procura daqueles que são tidos por sábios: homens de Estado, poetas e artífices de Atenas. Faz isso para refutar o oráculo, o qual afirmava que Sócrates era o homem mais sábio que existia.

Ao procurar um dos homens de Estado, percebeu que este apenas passava-se por sábio "Tentei, por isso, demonstrar-lhe que se enganava, ao julgar que era sábio. Isto me 
fez incorrer na sua inimizade, bem como na maioria dos que assistiam à nossa conversa" (PLATÃO, 1972, p. 72). A partir de sua peregrinação em busca de algum sábio, conclui

Sou, sem dúvida, mais sábio que este homem. É muito possível que qualquer de nós nada saiba de belo nem de bom; mas ele julga que sabe alguma coisa, embora não saiba, ao passo que eu nem sei nem julgo saber. Parece-me, pois, que sou algo mais sábio do que ele, na precisa medida em que não julgo saber aquilo que ignoro (PLATÃO, 1972, p. 72).

Entre artífices, poetas e homens de Estado, o filósofo não encontra sábios. Para Sócrates, sua diferença residia no reconhecimento de sua ignorância, de sua falta, seu não saber. Acusado de corromper a juventude de sua época e de não acreditar nos deuses, introduzindo novas divindades, Sócrates dava-se a tarefa de investigar, entre cidadãos e estrangeiros, quem seria sábio.

Foi esta investigação, Atenienses, que me valeu muitas inimizades, tão duras e tão graves que originaram muitas calúnias e o nome de sábio que me passou a ser aplicado. É que os que assistem a estas discussões pensam sempre que eu sou sábio naquelas matérias em que demonstro a ignorância dos outros (PLATÃO, 1972, p. 74).

Refutando a sabedoria daqueles que se diziam sábios, Sócrates despertava a malquerença de muitos. Despidos diante do filósofo, era demonstrado que não possuíam aquilo que tanto afirmavam ter: a sabedoria. A isso, Sócrates mantinha-se vigilante e dizia “O mais sábio de vós, ó mortais, é aquele que, como Sócrates, reconheceu que o seu saber é, na verdade, inteiramente desprovido de valor" (PLATÃO, 1972, p. 74).

O valor da ignorância! Louvamos a grande virtude de Sócrates: reconhecer-se não sabedor, um ignorante que não se acomoda, mas inquieta-se diante daquilo que desconhece. O presunçoso do saber não pode ter a atitude do ignorante que deseja o saber mais que tudo, que valoriza a própria ignorância como forma de saber. Antes, o soberbo pode se estribar no que conhece e desfrutar de sua vaidade, deleitar-se no seu saber.

Em relação a esse terreno movediço, que é o saber, Sócrates sempre se empenhou em refutar aqueles que afirmavam possuí-lo. Para o filósofo, aquilo que sabemos está em constante dúvida e mutação. Em um de seus diálogos, Êutifron questiona o fato de que Sócrates coloca em movimento as afirmações, ao passo que se dependessem de Êutifron, permaneceriam no mesmo lugar, ao que Sócrates responde: 
Então, meu caro amigo, sou capaz de ser mais hábil do que Dédalo² na sua arte, porque ele só dotava de movimento as suas próprias obras, ao passo que eu, ao que parece, dou esta faculdade não apenas às minhas, mas também às dos outros. E o que há de mais extraordinário na minha arte é que a pratico sem querer, porque o que eu desejaria, mais ainda do que ter os tesouros de Tântaro ${ }^{3}$ acrescentados à arte de Dédalo, era que os meus raciocínios fossem firmes e não se movessem do seu lugar. Mas basta de brincadeira! (PLATÃO, 1972, p. 45).

Admoesta-nos o filósofo para o reconhecimento de que não sabemos, pois aquilo que acreditamos saber precisa ser posto em dúvida a todo instante. Sócrates exalta a ignorância no momento em que a considera uma forma de saber.

O não saber nos atravessa e a busca pelo conhecimento nos persegue. Pausa. Movimento. Desafio. Silêncio. Tempo. Palavras inimigas e palavras amigas. A observação daquilo que nos move com respeito e cuidado minucioso. Pontos que se cruzam e se tecem, cosendo um bordado com seus buracos. As lacunas fazem parte, as brechas estão lá e deveriam estar. Não temos as respostas. Temos o silêncio. Temos a ausência.

É nesse ponto que todos se encontram: é no dar-se conta de sua falta, para então, colocar-se a saber algo. Para tanto, há que se admitir iguais, iguais em ignorância, iguais em possibilidade, iguais em inventividade. Professores e estudantes, na escola, declarados como iguais. Igualmente certos do seu não saber, igualmente certos de sua capacidade de mover. Portanto,

A educação não é uma tarefa de homens sábios, mas sim de homens emancipados. [...] E um espaço de emancipação porque aí a única coisa que se aprende é a própria potência: que se pode ler por si mesmo, escrever por si mesmo, pensar por si mesmo, e conversar com outros sobre o que se lê, o que se escreve e o que se pensa. (LARROSA, 2015, p. 152-154)

\section{Potência. Igualdade.}

Educação como espaço que se cria deslocando o lugar de professor e aluno, desconstruindo a bipolarização, alunos e professores, e partindo de um "nós" igualitário "Não como idênticos, mas sim como iguais" (LARROSA, 2012, p.158). Igualmente sujeitos de potência, emancipados, sabedores de que "Para emancipar um ignorante, é

\footnotetext{
${ }^{2}$ Dédalo foi o criador do labirinto.

${ }^{3}$ Nome de um dos reis asiáticos conhecidos por sua riqueza.
} 
preciso e suficiente que sejamos, nós mesmos, emancipados” (RANCIÈRE, 2015, p. 34).

$\mathrm{O}$ mestre que não sabe, que ensina aquilo que ignora, que se descobre na falta. $\mathrm{O}$ mestre que trabalha no desafio, que se mobiliza, que compreende a educação como tarefa de emancipados, que não deseja o "pronto e acabado", mas reconhece a lacuna como inventividade.

Concordamos com Larrosa (2015, p.65) ao dizer que "não podemos confiar naqueles que sabem imediatamente o que é preciso fazer para que as coisas sejam de outra maneira, e muito menos nos que dizem, sem se envergonhar o que é que os demais deveriam fazer". Admitir a capacidade de estar errado, admitir nossos limites. Preferimos o desconforto da inventividade, da experiência, do não saber. "A experiência tem a ver com o não-saber, com o limite do que sabemos" (LARROSA, 2015, p. 69).

Entre o saber e não saber dos professores, nossa pesquisa navega entre o pressuposto epistemológico daquilo que os professores julgam ausente e presente, entre o que acreditam (não) conhecer, sendo essa ignorância necessária para trazer à existência aquilo que ainda não existe, para inventar. Para tanto, é preciso compreender a igualdade de inteligências e a incompletude comum a todos nós, seres aprendentes, que não possuem o domínio do conhecimento, o estar cheio, saciado, preparado. É preciso saber que não sabemos e que não estamos preparados. As brechas permanecem, os buracos fazem parte do coser da toalha. $\mathrm{O}$ mar não tem cabelos. Estamos à deriva.

\section{A experiência do fora: entre (não) saberes e inventividade na escola inclusiva}

O perigo, o navegar, a sedução da imprevisibilidade, a beleza da tormenta, a travessia, o risco. Ele mesmo é o caminho, o movimento, a distância a ser percorrida. Blanchot (2005) nos convida a esse risco literário num encontro com o imaginário. Resgatando uma das aventuras de Ulisses em Ilíada, o escritor nos envolve narrando o episódio em que Ulisses goza do espetáculo das Sereias, sem correr o risco de ser envolvido por Elas, num gozo covarde e seguro. Ah! A segurança! Blanchot (2005) nos alerta como é conveniente e medíocre o comportamento de Ulisses.

Contudo, avistamos outras possibilidades em Ulisses, afinal, a fala da literatura nos permite tal ousadia pois é uma linguagem de rebeldia, transgressão, subversão. Uma linguagem errante que não deseja se fixar, que se alimenta pela insuficiência e impossibilidade. Vemos a igualdade e a emancipação nesse episódio de Ilíada. As Sereias

RIAEE - Revista Ibero-Americana de Estudos em Educação, Araraquara, v. esp, n. 3, p. 2054-2070, dez., 2018. E-ISSN: 1982-5587. 
experimentando, pela primeira vez, o sabor de serem moças reais; Ulisses escutando o canto enigmático e sobrevivendo a ele; os demais tripulantes, gozando ineditamente o prazer de ter o chefe na condição de dominado (BLANCHOT, 2005). Ineditismo do momento, experiência que atravessa e marca pela singularidade, por nunca ter sido vista, pela originalidade. A inventividade do autor, a inventividade da linguagem literária. Sereias, Ulisses e a tripulação sendo "desposicionados" do lugar que deveriam ocupar, experimentando uma forma de viver e pensar que não foi destinada a eles.

\section{Ineditismo. Igualdade. Emancipação.}

A experiência do fora para Blanchot (2005, p. 115) tem a ver com essa fala errante, que está na estrada, que é por vir e que se opõe à estabilidade, que só pode acontecer com seres deslocados, feita por "habitantes temporários, recusando a tentação de um mundo fechado (...) o deserto, aquele lugar sem lugar onde somente a aliança pode ser concluída e ao qual é preciso voltar constantemente".

O fora, a experiência do deserto que nos seduz pois

Nele, pode-se apenas errar, e o tempo que passa nada deixa atrás de si, é um tempo sem passado, sem presente, tempo de uma promessa que só é real no vazio do céu e na esterilidade de uma terra nua, onde o homem nunca está, mas está sempre fora. O deserto é o fora, onde não se pode permanecer (BLANCHOT, 2005, p. 115).

Sim! O professor pode errar! A possibilidade do testar, saborear, experimentar porque é errante, porque está em movimento. A experiência do deserto é a experiência do fora: uma habitação temporária na qual existe a liberdade, a promessa, o por vir que sempre é o ainda não. Lugar de movimento ao qual sempre devemos voltar e no qual se faz uma aliança "a indomável força própria da fraqueza, como se, quando não podemos mais nada, aparecesse às vezes o recurso de um poder muito diverso. Mas em que insegurança ela permanece!" (BLANCHOT, 2005, p. 147).

Nas ruínas encontramos a força, o poder da fraqueza. Contudo, essa força não nos traz segurança pois ela mesma é frágil e indomável.

$\mathrm{O}$ fora, o lugar da impossibilidade. $\mathrm{O}$ abandono do porto e o risco do viajante. $\mathrm{O}$ deserto e o oceano. Lugares que se encontram pelo excesso; lugares que se encontram pela falta. O peregrino que não sabe o que vai enfrentar, o enigma dos mares revoltos e da 
miragem pelo sol escaldante. Lugares de errância. $O$ transbordamento e a seca. Transbordamento de água/areia, ausência de terra seca/terra molhada. O saber e o não saber: presença na ausência do viajante que caminha no 'outro de todos os mundos'. O errante se perde pela imensidão (do deserto/ do oceano) e em ambos os não-lugares há pouca condição de sobrevivência.

Nesse desfazimento há vida, há verdade, há criação. $\mathrm{O}$ professor errante, o peregrino que se perde e se encontra no risco, no canto das Sereias. Esse mestre já não é eficiente e breve, objetivo nas explicações, com maior precisão de informações no menor espaço de tempo. $\mathrm{O}$ mestre envolvido pelos enigmas dos mares e peregrino no deserto nunca é explicador pois está ele mesmo se dando a conhecer. Ele não é como "os trapaceiros da experiência: eles nos fazem reunir, nos obrigam a falar e nos induzem a escutar somente sobre as coisas que acontecem [...]". O mestre da experiência tem seu discurso epistemológico baseado no provisório e entende que “A experiência é a experiência daquilo que sabemos que não poderemos, que nunca poderemos" (SKLIAR, 2012, p. 21)

Riscos são intrínsecos ao conhecer. Ensinar exige risco, aceitação do novo. Esses elementos carregam a potência da originalidade, do confronto constante e do colocar em suspenso o que se sabe. A curiosidade que não se satisfaz, o conhecimento que é rebelde, que não pode ser domado. Portanto, o conhecimento abriga a incerteza, o risco, a dúvida, uma vez que está sujeito à ilusão e ao erro. Aquele que se dispõe a conhecer carrega em si mesmo a virtude de enganar-se, encontrar respostas, perder-se nelas, voltar a encontrar-se, descobrir-se nelas e com elas.

Eis o elogio da escola: ela é o lugar que consegue trazer à vida. Destacando as características que fazem a escola ser escola, Masschelein e Simons (2015, p. 43) manifestam que ela é "uma questão de atenção e de mundo". A escola tem a capacidade de abrir, criar o interesse e formar. "Leva-nos para fora de nós mesmos (...) expostos ao mundo e convidados a se interessarem por ele" (MASSCHELEIN; SIMONS, 2015, p. 52).

Um espaço onde tudo cai. A escola tem sido local onde tudo acontece. Ela precisa "dar conta" das demandas que já existem e daquelas que são acrescidas, mesmo sendo acusada "de ser um maquinário normalizador, colonizador e alienante" (MASSCHELEIN; SIMONS, 2017, p. 19)

A escola, enquanto invenção da pólis na Grécia, tinha o objetivo da democratização do tempo livre (MASSCHELEIN; SIMONS, 2014, p. 107). Ela oferecia 'tempo livre' para aqueles que, de acordo com seu berço e seu lugar na sociedade, não poderiam dispor de tal 
tempo. A escola configurava-se, não obstante sua característica excludente quanto às mulheres e escravos, como um espaço de transgressão do privilégio dos aristocratas e cavaleiros gregos.

Ser separado para desempenho especial de uma tarefa a que os demais não teriam a capacidade de desenvolver. O conhecimento como privilégio e divisor de águas: entre os que podem (saber/opinar/escolher/pensar/dizer) e os que não podem. A escola, esse espaço epistemologicamente democrático do saber, iguala os sujeitos ao oferecer-lhes a possibilidade de que todos podem. "As reclamações sobre a escola, de que ela não serve para nada, que são comumente ouvidas atualmente, aponta para o que a escola é de fato: a escola é a separação da vida produtiva e é constituída para todos e cada um" (MASSCHELEIN; SIMONS, 2014, p. 109)

As escolas públicas democráticas despertam aquilo que Rancière (2015) descreve como medo e até ódio à democracia, uma vez que só estavam autorizados a exercer o poder aqueles que tivessem qualificações específicas para tanto, poderes como a riqueza, o nascimento ou o saber. A percepção de que todos são capazes desmistifica a hierarquia de inteligências e abala as fronteiras entre os que julgam saber ou não saber. Um encontro de iguais pela falta, pela ignorância. Não há habilitados ou inabilitados, capazes e incapazes. Há, tão-somente, incompletude e desejo num espaço do possível.

Contra essa hierarquia, reivindicamos o direito de falar e de escutar, tanto do professor quanto do estudante. Nada de asfixiar o outro, de fazê-lo submisso, certo de uma condição inferior. Nada de reforço ao autoritarismo, mas sabedores de que é escutando o aluno, paciente e criticamente, que se aprende a falar com ele. Falar com. Isso significa não considerar o outro seu objeto, mas vê-lo na condição de sujeito da fala e da escuta. $\mathrm{O}$ professor explicador, ao contrário, detém todo o tempo para suas explanações.

O poder da palavra. O poder daquele que fala. Resgatando a dialética do Senhor e o escravo, em Hegel, Blanchot (2005) esmiúça algumas questões intrigantes da relação entre o ouvinte e aquele que fala

É assim que a linguagem nos joga na dialética do mestre e do escravo, que nos obceca. $\mathrm{O}$ mestre adquiriu direito à fala porque foi até o extremo do risco de morte; só o mestre fala, uma fala que é comando. O escravo apenas ouve. Falar, eis o que é importante; aquele que só pode ouvir depende da fala, e vem somente em segundo lugar. Mas a escuta, o lado desfavorecido, subordinado e secundário, revela-se finalmente como o lugar do poder e o princípio da verdadeira autoridade. (BLANCHOT, 2005, p. 45) 
Dependência. Essa é a relação entre o mestre e seu discípulo quando um deve falar e o outro ouvir. A escuta aqui tem sua raiz epistêmica não no sentido da atenção, mas da submissão, daquele que depende do interpretador para compreender as coisas. O discípulo é aquele que está em segundo lugar na desigualdade de inteligências. Como na retórica, não há busca da compreensão, mas do "aniquilamento da vontade adversa [...] Ela fala para fazer calar" (RANCIÈRE, 2015, p. 122). Ele só pode ouvir, enquanto seu mestre só pode dizer. O embrutecedor exerce sua autoridade enquanto mantém-se acorrentado ao escravo, o subordinado que detém o poder. Como registra Skliar (2017, p. 233) "a explicação não é outra coisa que a invenção da incapacidade do outro".

$\mathrm{O}$ mestre embrutecedor tem inventado o incapaz e se acorrenta a ele. O mestre explicador "aumenta de tamanho na mesma proporção que se faz diminuto o corpo do aluno. E na medida em que o mestre aumenta a extensão de sua explicação, o corpo do aluno vai ficando cada vez menor" (SKLIAR, 2017, p. 233). O que não percebe o mestre da fala é que o lado desfavorecido da escuta é lugar de poder.

A escola, ao retirar a noção de alguns escolhidos para exercer o direito ao conhecimento, torna possível a busca pelo conhecimento de maneira igualitária. Com seus exercícios e formas próprias de estudo, trabalha as informações, confrontando os saberes, duvidando das certezas, criando, refletindo e produzindo novas formas de existência e de conhecimento.

Larrosa (2015, p. 18-20) nos convida a pensar no excesso de informação que sufoca o conhecimento "como se aprender não fosse outra coisa que não adquirir e processar informação". Para ele, há um excesso de opinião: "a opinião, como a informação, converteu-se em um imperativo" e essa obsessão anula nossas possibilidades de experiência. $\mathrm{O}$ autor escreve que a informação é quase uma antiexperiência.

Nesse sentido, o conhecimento implica informação, mas também dar-se a conhecer, investigar, desconfiar e saber. A escola é lugar de experiência. A escola é espaço no qual se reivindica uma forma de viver e pensar que não foi destinada aos que nela estão, a um deslocamento, uma desocupação. Esse desposicionamento, essa saída do lugar que "lhes pertence" corresponde àquilo que Rancière (2015) denomina emancipação.

Ao falar sobre emancipação, Rancière (2015) nos apresenta um mestre néscio chamado Jacotot, que tendo contato com estudantes holandeses decide iniciar suas aulas sem aprender o idioma local. O professor domina o francês e apresenta uma versão 
bilíngue (francês-holandês) do Telêmaco, com a qual passa a lecionar.

Escrevendo acerca das "lições" de emancipação, Rancière (2015) nos diz que uma vontade (a do aluno) pode estar ligada ou obedecer a outra vontade (a do professor), todavia a inteligência não obedece a outrem senão a ela mesma (no caso Jacotot, a inteligência seria o próprio Telêmaco). Acerca da emancipação, Rancière (2015, p.34) escreve "pode-se ensinar o que se ignora, desde que se emancipe o aluno (...) que se force o aluno a usar sua própria inteligência”. Para tanto, é necessário que seja o próprio mestre emancipado, que ele mesmo se dê conta de sua (in)capacidade.

Como nos ensina Rancière (2015, p. 34) “o ignorante aprenderá sozinho o que o mestre ignora, se o mestre acredita que ele o pode, e o obriga a atualizar sua capacidade". A isso o autor denomina círculo da potência, no qual o ignorante é capaz de aprender por si mesmo sem que haja um explicador. Da mesma forma que o círculo da impotência liga o aluno ao explicador, o círculo da potência liga o aluno ao mestre ignorante.

O espaço escolar, ao tornar possível essa emancipação, revela o segredo epistemológico do conhecimento pois partilha os saberes entre sujeitos que podem ou não aprender, podem ou não acessar, podem ou não divulgar, distanciando a pessoa de si mesma "A emancipação não é uma mudança em termos de conhecimento, mas em termos de posicionamento dos corpos [...]. Esse novo lugar "reconfigura o território do dizível, visível, pensável e possível” (MASSCHELEIN; SIMONS, 2014, p. 87-88)

A escola permite a reconfiguração do lugar do sujeito. Como Larrosa (2015, p. 25) denomina, o sujeito está ex-posto (o que já não está mais posto), numa "ex-posição", por isso vulnerável, correndo o risco porque é sujeito da experiência e pode ser derrubado. Nada garante a permanência de sua posição, ao contrário do sujeito da não-experiência pois "nada o ameaça, nada lhe chega, nada lhe ocorre".

A experiência em Rodríguez nos revela esse território, esse novo lugar. Estando na Jamaica, Rodríguez vive esse "acontecimento" com Thomas, uma criança pobre e analfabeta que apresenta uma solução inusitada para alguém na sua condição. Brincando com as crianças, Rodríguez lança um chapéu na tentativa de encaixá-lo num vaso que está na varanda de uma casa. Quando consegue o feito, resta a dúvida: como resgatar o chapéu? A solução para o problema parte de Thomas: as crianças poderiam subir nos ombros do professor e assim resgatariam o objeto.

Um problema aparentemente simples, mas o que surpreende é a alternativa de Thomas, bem diversa da que pensara o mestre (pegar uma escada ou pedir o chapéu de volta a um dos mordomos). Talvez exatamente por essa condição a criança pode inventar. 
Por ver aquilo que os outros não enxergam, “Thomas é um irreverente. Ele não faz o que se supõe que deve fazer uma criança de sua condição" (KOHAN, 2015, p. 34).

Para nós, Thomas ensina a emancipação citada por Rancière. Ele sai da sua condição, desterritorializa, surpreende, desposiciona. Para isso deve se direcionar o professor, para "ajudar aos outros a encontrar o que eles são" (KOHAN, 2015, p 84). A isso se dedicava Rodríguez, o viajante educador, o filósofo professor que vivia a experiência da errância. Talvez por isso sua originalidade, sua busca por fazer escola e por ajudar os outros a serem quem são. Aqui, o fazer escola é inventar, é fazer "de verdade" aquilo que ainda não ganhou vida, o que não deu à luz.

Para Jacotot e Rodríguez, o método não é considerado o mais importante “cada professor deve escolher seu caminho, e a verdadeira luta passa por pensar por que e para quê faz o que faz, a partir de qual princípio e com qual sentido educa do modo que educa" (KOHAN, 2015, p. 118). A esse pensamento, afinamos a ideia de Rancière (2015, p. 50): "Não é, pois, o procedimento, a marcha, a maneira que emancipa ou embrutece, é o princípio".

Depois de Thomas, Rodríguez vive uma nova vida e já não pode ir à escola como antes (KOHAN, 2015). Pequenos-grandes encontros que atravessam, que ressignificam. Thomas parece ter ensinado "de verdade", parece ter inventado. Como Kohan (2015), acreditamos que as crianças e os loucos dizem verdades, domados por uma fala irresponsável, quase delirante. As crianças são observadoras: observam umas às outras, observam as coisas que passam despercebidas pelos adultos, observam com sensibilidade, a base do saber e do pensar.

A escola parece ser o espaço do presente (de alguns) e do futuro (de pouquíssimos que sobreviverem a ela). À espera de condições ideais, pessoas aptas, capacitadas... à espera da perfeição! Estamos contra a perfeição. Aos errantes, aos desvalidos... a escola pode ser o lugar desses seres da improdutividade. Como Rodríguez, precisamos aprender a arriscar. Kohan (2015, p.53) nos recorda: "Ele se joga e se compromete, mesmo quando não estão dadas as condições para isso. Fará seu mea culpa, mas nunca deixará de fazer algo, mesmo imperfeito, por esperar que estejam dadas as condições ideias para o seu trabalho".

Esperar do inesperado, a surpresa, de onde não haveria possibilidade, do infértil, do deserto. A solução pode vir de um Estudante com deficiência, daquele que figura, do irreverente... "ele não faz o que se supõe que deve fazer uma criança na sua condição", diz Kohan (2015, p. 53) acerca de Thomas e da experiência vivida com Rodríguez. Aqui, 
dizemos o mesmo para mostrar nossa escola e a condição da deficiência dentro dela. $\mathrm{O}$ Estudante com deficiência não faz o que se supõe que deve fazer uma Pessoa na sua condição.

Talvez, ao reconhecer que não há nada a dizer, o mestre diga muito mais a seus Estudantes. O trato da informação, a transformação do conhecimento para ser "melhor entendido", para que esteja acessível ao Estudante, como se ao professor estivesse disponível a fartura e, dentre esse arsenal, o professor elegesse os alimentos menos indigestos, aqueles possíveis de serem absorvidos rapidamente pelo corpo sem maiores prejuízos. Se a obra se faz na ruína, se é em meio aos escombros que podemos encontrar vida, então é na destruição que se revela a presença. O "fora" para Blanchot (2005) é o próprio 'desobramento'. No lugar de construir, o desconstruir; no lugar de obrar, o desobrar; no lugar da presença, o abandono, lembrando sempre que "Algumas presenças parecem ausências. Algumas ausências ocupam tudo" (KOHAN, 2015, p. 39). No lugar aqui significa não a substituição, a retirada de um elemento e a inclusão do outro. No lugar aqui quer dizer "no mesmo lugar", uma dupla convivência, uma contradição que sustenta a vida.

Estamos com Levy (2011, p. 35) quando diz: "Experimentar o fora é, pois, fazer-se um errante, um exilado que se deixa levar pelo imprevisível de um espaço sem lugar, pelo inesperado de uma palavra que não começou, de um livro que está ainda e sempre por vir". A errância, um explorador, um visitante, um alguém que vaga, um errante no sentido da mudança contínua, do nômade que também pode vacilar, que erra, tropeça e cai porque não conhece o espaço sem lugar pelo qual vagueia... um incerto. Nesse andar ao acaso está sempre "por vir", sempre no "ainda não". A beleza da não chegada, o desafio da impossibilidade, do reconhecimento de nossa igualdade pela (im) potência. "Arte feliz é, portanto, aquela que se desobra para o fora [...] ao desobrar para fora do mundo, nossos valores e certezas são questionados. Nesse sentido, a experiência do fora nada mais é do que uma experiência revolucionária, contestadora” (LEVY, 2011, p. 38).

Procuramos o indizível, para que "cada palavra seja diferente a cada vez, que difira o tempo todo de si mesma [...] para que a palavra não seja, se é que é possível, uma pronunciação já conhecida" (SKLIAR, 2012, p. 28). Procuramos o inesperado, para que nos penetre, para que vivamos com outras palavras, outros significados, para que sejamos nós mesmos emancipados e (não) sabedores. Como Levy (2011) também desejamos que as palavras aqui estejam sempre em suspenso, num tremor que não permitam permanecer no mesmo lugar. Procuramos o professor errante, que habite a morada temporária, que se 
alimente na errância.

O reconhecimento da escassez não garante a segurança. Ela não pretende tal cilada. Entretanto, o poder da fraqueza nos constrange, ele nos choca, atravessa o peito mostrando que simplesmente não podemos, não sabemos, não damos conta. Há um trecho no caminho que é desconhecido, há um penhasco, há um risco, há um não poder. Se sou incapaz de explicar, se sou incapaz de poder, desisto da tentativa (já fracassada desde a largada) de colocar na cabeça do outro, de ofertar-lhe sua parte, seu quinhão, seu pedaço de pão para garantir o sustento do dia. Ao contrário, não the dou nada, ambos passam fome, ambos sobrevivem na carência, na sede, na necessidade, pois não tenho a dar e ele não tem a receber. Mas essa carência potencializa a ambos, e pode proporcionar (quem sabe?) um banquete.

\section{Considerações finais}

Nesse pequeno baú levamos muitas dúvidas. Nele também cabem (não) saberes e presenças que são também ausências. Dentro dele está o desencontro, a incompletude e o risco.

Da capacidade de poder dizer está a potência do nascimento de outras palavras que ainda não foram ditas. Não se cria o que já existe. Não se inventa o que se sabe. Em nosso pressuposto epistemológico do (não) saber, precisamos ultrapassar o posto, o vivido, o sabido, o imitado, o que tudo sabe e, por tudo saber, já não tem forças para dizer algo novo. Conhecer para intervir e inovar. Precisamos inventar!

A escola nos desafia, move, inventa, constrange, mostra aquilo que não sabemos. É no reconhecimento da incompletude, do nosso (não) saber, do desafio que a escola lança diante do vazio que precisa ser campo de inventividade que encontramos caminhos para esse artigo.

Quando o professor se vê desafiado pelas circunstâncias do cotidiano escolar, quando as situações novas o indagam e ele não sabe as respostas, esse habitante temporário reconhece sua ignorância e seu (não) saber permite o erro, a descoberta do novo e a possibilidade da inventividade no espaço escolar.

A educação inclusiva sempre foi um desafio. O reconhecimento de que a deficiência traz consigo muitos questionamentos para os quais os professores não encontram as respostas revela que ainda há muito por saber, há muito a duvidar. 
É nesse desconhecimento que reside a produtividade. Enquanto sujeitos de possibilidades, e não de certezas, os professores constroem suas práticas e saberes. Nesse contexto, não cabe falar em manuais, fórmulas e exemplos a serem seguidos; não cabe falar em homem padrão, em homogeneidade.

Parece-nos que a presença do Estudante com deficiência desperta no professor sentimentos de inquietação, receio, incerteza, dúvida, sentimento de quem tem medo por não saber, mas, ao mesmo tempo, de quem pode inventar. Há pequenos poros por onde se respira, por onde se recupera o fôlego necessário ao improviso, à tentativa, à experiência. Nada garante o sucesso, mas ainda temos a chance de tentar.

\section{REFERÊNCIAS}

BLANCHOT, Maurice. O livro por vir. Trad. Leyla Perrone-Moisés. São Paulo: Martins Fontes, 2005.

LARROSA, Jorge. Dar a palavra. Notas para uma dialógica da transmissão. In: LARROSA, Jorge.; SKLIAR, Carlos (orgs). Habitantes de Babel: políticas e poéticas da diferença. Trad. Semíramis Gorini da Veiga. $2^{\mathrm{a}}$ ed. Belo Horizonte: Autêntica Editora, 2011.

LARROSA, Jorge. O enigma da infância ou o que vai do impossível ao verdadeiro. In: LARROSA, Jorge.; LARA, Nuria Pérez de. Imagens do outro. Trad. Celso Márcio Teixeira. Petrópolis: Vozes, 1998.

LARROSA, Jorge. Pedagogia profana: danças, piruetas e mascaradas. Trad. Alfredo Veiga-Neto. $5^{\text {a }}$ ed. Belo Horizonte: Autêntica Editora, 2016.

LARROSA, Jorge. Tremores: escritos sobre experiência. Trad. Cristina Antunes e João Wanderley Gerladi. Belo Horizonte: Autêntica Editora. 2015.

LEVY, Tatiana Salem. A experiência do fora: Blanchot, Foucault e Deleuze. Rio de Janeiro: Civilização Brasileira, 2011.

MASSCHELEIN, Jan.; SIMONS, Maarten. A pedagogia, a demoracia e a escola. Belo Horizonte: Autêntica Editora, 2014.

MASSCHELEIN, Jan.; SIMONS, Maarten. A língua da escola: alienante ou emancipadora. In: LARROSA, J. Elogio da escola(org). Trad. Fernando Coelho. 1 ed. Belo horizonte: Autêntica Editora, 2017.

MASSCHELEIN, Jan.; SIMONS, Maarten. m defesa da escola: uma questão pública. Trad. Cristina Antunes. 2 ed. Belo Horizonte: Autêntica Editora, 2015. 
PLATÃO. Êutifron. Apologia de Sócrates. Críton. Trad. Manuel de Oliveira Pulquério. Lisboa: Editorial Verbo, 1972.

RANCIÈRE, Jacques. O espectador emancipado. Trad. Ivone C. Benedetti. São Paulo: Editora WMF Martins Fontes, 2012.

RANCIÈRE, Jacques. O mestre ignorante: cinco lições sobre a emancipação intelectual. Trad: Lílian do Valle. 3 ed. Belo Horizonte: Autêntica Editora, 2015.

SKLIAR, Carlos. Experiências com a palavra: notas sobre linguagem e diferença. Rio de Janeiro: Wak Editora, 2012.

SKLIAR, Carlos. Jacotot-Rancière ou a dissonância inaudita de uma pedagogia (felizmente) pessimista. Educação e Sociedade. Campinas, v. 24, n. 82, p. 229-240, abr., 2003.

\section{Como referenciar este artigo}

SEPTIMIO, Carolline.; MENDES, Geovana Mendonça Lunardi.; COSTA, Gilcilene Dias da. Habitantes temporários: o pressuposto epistemológico do (não) saber docente e a inventividade. Revista Ibero-Americana de Estudos em Educação, Araraquara, v. esp, n. 3, p. 2054-2070, dez., 2018. E-ISSN: 1982-5587. DOI: 10.21723/riaee.unesp.v13.iesp3.dez.2018.11145.

Submetido em: 28/02/2018

Revisões requeridas: $12 / 04 / 2018$

Aprovado em: 26/07/2018 